\title{
Pluriactivity and Socio-economic Success of Rural Households
}

\author{
L.R. de Silva and K.A.S.S. Kodithuwakku*
}

\begin{abstract}
The past few decades have seen a transformation in Sri Lanka from a traditional agricultural based rural economy to a more diversified economy leading to more pluriactive farmers. Pluriactivity has been identified as a survival and/or capital accumulation strategy. However, available literature reveals that all the pluriactive households are not socio-economically betteroff. The objective of the research is to compare and contrast better-off and worse-off pluriactive households in a given locality. This is in terms of the nature of income generation activities carried out by them and will be discussed in line with theories of entrepreneurship.

Multiple embedded case study strategy was adopted. This was in order to explore meanings attached to socio-economic behaviours as perceived by the rural households. The research was carried out in a selected village in Kurunegala district, Sri Lanka. Initially, households were divided into soio-economically better off and worse off groups based on information gathered from key informants and subsequently, two samples were drawn from each group. Multiple data collection methods such as in-depth interviews, group discussions and direct observations were used. The data were analysed qualitatively and the findings were supplemented with quantifiable evidences whenever necessary in order to increase the validity of conclusions.
\end{abstract}

The study site was a typical example of a resource constrained environment and pluriactivty has been adapted by both groups in order to increase their household income. However, the better off households have diversified into more off farm income generation activities and hence their dependency on agriculture was lower than that of worse off households who were mainly dependant on agricultural activities. In addition, the better off households exhibited more entrepreneurial qualities as they extract values from the environment without regard to the resource owned by them.

The authors are, respectively, Final Year Undergraduate Student at the time the study was conducted and Senior Lecturer in the Department of Agricultural Economics and Business Management, Faculty of Agriculture, University of Peradeniya. 


\section{Introduction and Overview}

The policies implemented to improve the rural sector in Sri Lanka have basically focused on farming activities even though the household is the key element in studying and understanding changes within the farm sector (Fuller, 1990). Pandya-Lorch and Braun (1992) contend that the rural households do not always have farming as their primary occupation and even if they do, they are much dependent on a variety of off-farm and nonagricultural income sources. Same scenario is visible in Sri Lanka as the Sri Lankan Integrated Survey (SLIS) (1999-2000) revealed that non-farm activities contributed $56 \%$ of the total rural household income whereas the contribution of crop cultivation, livestock and casual agriculture wage labour was only $23 \%$.

A household moving into more than one income generation activity is defined as diversification (Ellis, 2000) and the significant shift towards diversification has led to consider improving household income through diversification as an imperative solution to the problem, poverty. Farmers' attempt to embrace (Clout, 1993) and maximize opportunities (Fuller, 1990) through diversification of income generation activities that eventually result in pluriactivity and improving household income. Evans and Ilbery (1993) had defined pluriactivity as the phenomena of farming in conjunction with other gainful activities, whether on or off-farm. Clout (1993) argues that diversification should be discussed in terms of pluriactivity if it is to be used as a solution to high levels of poverty. This enables the development of farm households which are a vital component of the village, thus contributing to integrated rural development (Rupena-Osolink, 1983).

Some authors have argued that certain households are pluriactive just to maintain their household income (Bowler et al., 1996) and/or to pay for necessities (Bowler et al., 1996). Kodithuwakku (1997) further argues that survival may not be the only reason for being pluriactive and when households are attracted by new opportunities pluriactivity is used to match opportunities with resources, which will ultimately result in wealth creation and accumulation.

Studies done in the Sri Lankan rural context reveal that the rural community of the country is a heterogeneous farming group with a minority of better-off households (Hettige, 1982; Gunathilake et al., 1992; 
Kodithuwakku, 1997). It is also evident from a recent study conducted by the Department of Agriculture that $82 \%$ of the Sri Lankan farm households are pluriactive (Deparment of Agriculture, 2000). According to the survey 'Consumption Poverty in Sri Lanka' the incidence of poverty is $25.17 \%$ and rural sector contribution to this is around 89\% (Deparment of Census and Statistics, 2000). This raises the question as to why a majority of Sri Lankan rural households are worse-off despite them being pluriactive.

\section{The Theoretical and Study Context}

Pluriactivity provides avenues to develop both individual and community well-being where the suitability of the concept of pluriactivity as a poverty reduction strategy can be understood by looking at its significance (Rupena-Osolink, 1983). It acts as a method of reducing income variances (Stark and Levhari, 1982) while improving household income (Fuller, 1990; Evans and Ilbery, 1993, De Vries, 1993) and their status (Fuller, 1990). According to Nikajima (1986) pluriactivity minimizes the risk due to uncertainties in agriculture and according to Hetland (1986) and Stark and Levhari (1982) it minimizes the risk of specialization. Its role as a selfinsurance activity minimizes the impact of a down turn in farm income and further allows farm income to be ploughed back into the farm (Weersink, 1998) or other ventures (Kodithuwakku, 1997). It also allows households to increase the utilization of family labor and under-employed surplus labor (Krasovec, 1983) and market integration (Dagher and Christy, 1991). This is by mobilizing human resources in an efficient and effective manner (RupenaOsolink, 1983). It also expands the social horizons as it enables them to diversify their ties into various other niches of the surrounding environment (De Vries, 1993). Pluriactivity makes it possible to achieve synergistic effects (Salter and Weinlold, 1981; Kodithuwakku and Rosa, 2002). McGrath (1996) had argued that pluriactivity provides access to information, experience and knowledge, which become the basis for moving into other income generation activities. As discussed so far, all the advantages obtained through pluriactivity allow them to achieve continued net viability and reproduction of the business (Evans and Ilbery, 1993) and progressive improvement of agricultural production (Rupena-Osolink, 1983). This in turn contributes to economic wealth, employment (Reynold et al., 1994), integrated rural development and national income (Rupena-Osolink, 1983). 
Though the concept of pluriactivity is imperative to enhance the socio-economic status of rural households as discussed above, it has not paved the path of success to all pluriactive households (Kodithuwakku, 1997). In a resource constrained and barren environment it is necessary to utilize resources efficiently and effectively and also go beyond resource limitations in order to achieve socio economic success (Vyankarnam, 1990; Kodithuwakku and Rosa, 2002). The spirit of entrepreneurship, according to the same authors, relies upon the ability to capitalize whatever the opportunities available in a given environment, which might also require the entrepreneur to go beyond the resource limitations. Kodithuwakku and Rosa (2002) contend that in extremely unpromising and constrained environments entrepreneurs become pluriactive in their attempt to maximize the capitalization of a myriad of smaller opportunities available in the given context, leading to portfolio-entrepreneurship. According to previous research studies the success through portfolio of income generation activities also depends on selection of proper combination of on and off farm activities (Krasovec, 1983), introducing components which are complementary to each other (Hetland, 1986), not having highly positively correlated (Schwab et al., 1989) and having more of related activities (Kodithuwakku, 1997).

According to Ucbasaran et al., (2000) biophysical and socio cultural environment in which an entrepreneur operates and the entrepreneurial skills possessed determine the ability of spotting opportunities and capitalizing upon the same. Ability to spot opportunities demands the possession of necessary data as well as cognitive ability to evaluate these while capitalizing opportunities provided by the environmental conditions (Ucbasaran et al., 2000) and the ability of matching resources with the opportunities, which is an entrepreneurial quality (Scott et al., 1997). This proves that pursuing of opportunities is contingent upon the way an individual perceives the environmental context (Stevenson and Jarillo, 1990). Success of entrepreneurs depends on how they have adapted to the changes in the environment (Bryant, 1989) and/or how they have changed the conditions in the environment (Schumpeter, 1934). Therefore it may be argued that entrepreneurial process cannot be taken in isolation from the environment of the entrepreneur (Beckford, 1993). The interrelationship between entrepreneurial skills and environmental conditions had been studied by Kodithuwakku (1997) in the Sri Lankan rural context and he argues that pursuing opportunities and mobilizing resources through social network is one of the most important approaches to success. According to him, the process of extracting values 
through social network enables entrepreneurs to overcome resource constraints, product market constraints, factor market constraints and the local environment constraint. Black (1986) contend that entrepreneurs utilize the social network as a method of sharing information, learning from other peoples' experience and obtaining investment funds.

In the resource constrained environment, reinvesting profits by delaying consumption, which is known as differed gratification had also contributed to achieve socio economic success (Kodithuwakku and Rosa, 2002).

The main objective of this research is to investigate differences between better-off and worse-off pluriactive households of a given rural location in terms of type of income generation activities carried out by them and entrepreneurial qualities exhibited.

\section{Research Methodology}

Case study methodology, in particular the multiple embedded case study design (Yin, 1994), was adopted.

Sampling decision commenced with the selection of a research site. The research was carried out under an ongoing project in Kurunegala district i.e. Sri Lanka Australia Natural Resource Management Project (SLANRMP), which is funded by the Australian Agency for International Development (AusAID). Baseline study reports and project site selection reports prepared by the project staff were used for the purpose of selecting a proper research site (Sri Lanka - Australia Natural Resource Management Project, 2004). Though SLANRMP has completed baseline studies of two project sites namely Walathwewa and Ihalathimbiriyawa, Iahlathimbiriyawa project site which is situated in Polpitigama District Secretariat (DS) division was selected as the appropriate research site as it consisted of pluriactive and heterogeneous (in terms of social well-being) households (Sri Lanka Australia Natural Resource Management Project, 2004). The village was treated as the physical boundary of the case study and households (130 in total) were treated as the units of analysis.

The population was stratified initially as better-off and worse-off households based on the information provided by key informants. The key 
informants were the Praja Niyamaka ${ }^{1}$ and two boutique keepers. Usage of key informants to obtain initial information regarding the population was a strategy, which had been widely adopted (Kodithuwakku, 1997; Tremblay, 1982; Johnson, 1982; Kodithuwakku and Rosa, 2002). In addition key informants acted as gatekeepers to the village. Kodithuwakku (1997) had also obtained the same advantage, which facilitated execution of data collection strategies. The sampling frame was presented before each key informant separately and they were asked to provide information on income generation activities carried out by each household in the population and on their differential socio-economic status (i.e. worse-off households and better-off with reasons).

Usage of the three key informants to obtain initial information enabled effective triangulation of information and thus enhanced the validity of the stratification of households. The information collected through key informants was then used to divide the population into two groups as 36 better-off households and 94 worse-off households. It was evident from the information provided by the key informants and base line study reports that the better-off households were having diverse composition of income generation activities and non-routine behavioural patterns. The non-similarity among the better-off households in terms of the income generating activities led to the selection of all of them to the sample. This was mainly due to the anticipation of researchers that such variability among income generating activities would provide an opportunity to have a complete understanding of the entrepreneurial behaviour in the given context. Unsuccessful households were grouped according to the type of their income generation activities and a proportionate sample of 36 was selected.

A complex phenomenon could be best approached through multiple data sources and methods since it improves the validity (Bonoma, 1985) and the reliability (Kirk and Miller, 1986) of the research. Therefore both primary and secondary data were obtained. Multiple methods such as in-depth interviews with key informants (Kodithuwakku, 1997), project staff and households, group discussions, direct observations (Hartley, 1989) and participating in village committee meetings were used to collect primary data. In-depth interviews were aided by an unstructured questionnaire. Fieldwork

${ }^{1}$ Praja Niyamaka is elected by villagers as the representative of the village in order to coordinate activities of the ongoing project. 
was carried out for a one month period. Secondary data were obtained from base line reports and project site selection reports produced by Sri Lanka Australia Natural Resource Management Project (SANRMP).

Qualitative data analysis was done and findings were supplemented by quantifiable evidence. "Within case analysis" was performed in order to identify the key processes within each sub case (Kodithuwakku, 1997) and "cross case analysis" was performed in order to identify patterns in terms of similarities and differences (Eisenhardt, 1989).

\section{Results and Discussion}

Environmental Context Influences Households to be Pluriactive. As mentioned in the literature the behaviour of households was drastically shaped by the environmental context in which they operate. The research site was an example of a resource constrained and harsh environment. As illustrated in Figure 1, lack of enough rainfall and irrigation facilities, which had the capability of providing irrigation water only to $28.44 \%$ of the total cultivated area (Sri Lanka - Australia Natural Resource Management Project, 2004), had restricted paddy cultivation only to the Maha season.

Figure 1: Rainfall distribution pattern and its effect on household behaviour

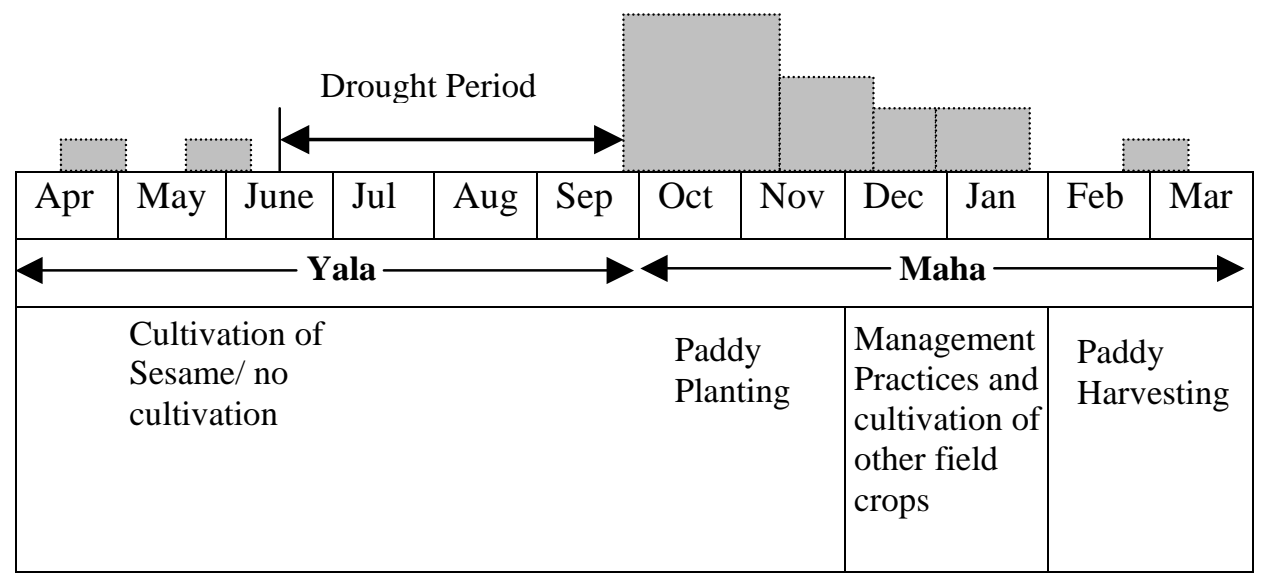

$=$ Rainfall 
Every year the months of July, August and September are characterized by the prevalence of a drought period. Being a site situated around a mountain had resulted in having a thin, rock-strewn and infertile soil conditions. Pervasiveness of limited market opportunities for paddy had escalated the severity of the situation. As illustrated in Figure 2, paddy and rice marketing is entirely run by two households namely, a boutique keeper (who receives paddy through paddy credit exchange and runs the only rice mill of the village) and a household (who operates a parboiling venture).

Figure 2: $\quad$ Paddy marketing channel

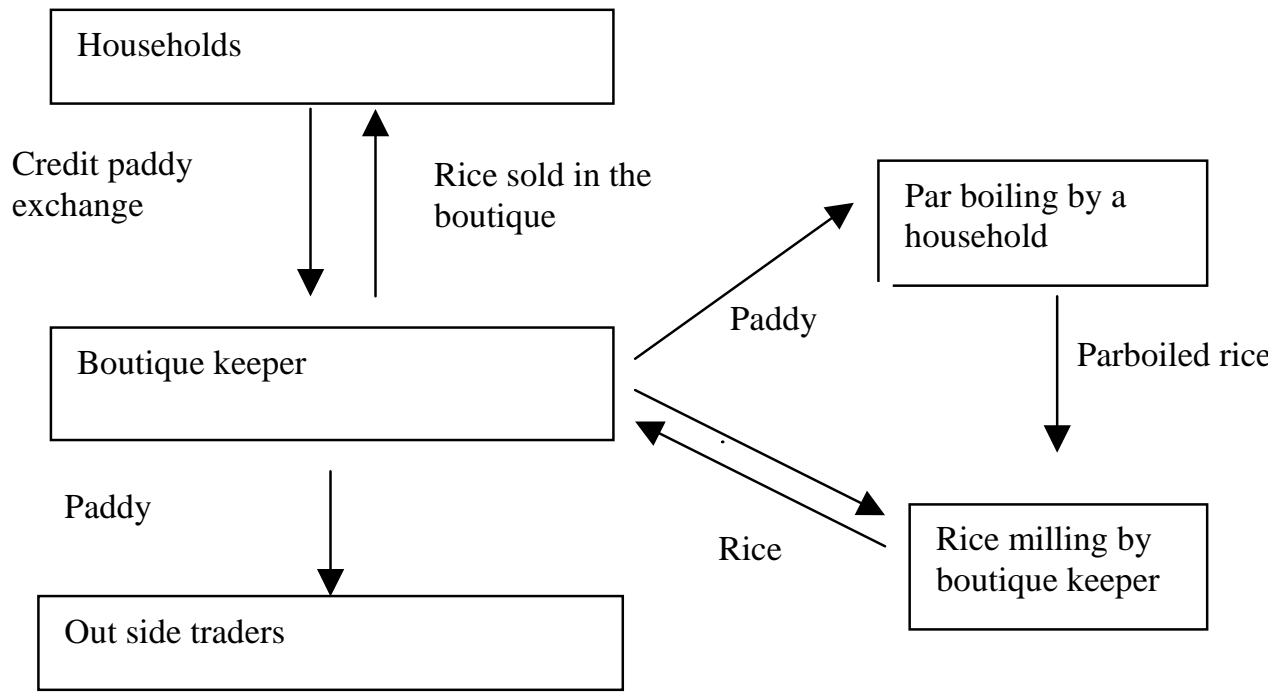

Low level of infrastructure facilities has made the situation further constrained. Other than four households that had generators and three households that had solar power electricity, the rest did not have electricity. Their only way of communication was the telephone at the boutique.

In this resource constrained environment, all the households engaged in more than one income generation activity. Despite everybody being pluriactive, only $27.7 \%$ of households were better off.

Both better-off and worse-off households were exhibiting similar behaviour in crop cultivation where paddy was cultivated only in Maha season and crop cultivation was not practiced during Yala season (due to lack 
of rainfall) except for sesame, which was sometimes cultivated if enough rainfall was received (Figure 1). The difference observed between these two groups in relation to crop cultivation was the level of importance placed on the income received through crop cultivation as a source of household income where the level of importance placed by better-off households was significantly lower than that by worse-off households. Sixty one percent of better-off households was receiving a permanent monthly income. A majority of better-off households was operating their own businesses (e.g. masonry work, boutique keeping, operating quarry, carpentry, and selling fish etc) in addition to the income obtained through paddy cultivation and permanent jobs (Table 1).

Table 1: $\quad$ Differences between better-off and worse-off households in term of type of income generation activities

\begin{tabular}{|c|c|c|}
\hline Category & Income generating activities & $\%$ \\
\hline \multirow{3}{*}{$\begin{array}{l}\text { Better-off } \\
\text { households }\end{array}$} & Monthly income + Crop cultivation & 38.9 \\
\hline & $\begin{array}{l}\text { Monthly income }+ \text { Own business }+ \text { Crop } \\
\text { cultivation }\end{array}$ & 22.2 \\
\hline & Own business + Crop cultivation & 38.9 \\
\hline \multirow[t]{3}{*}{$\begin{array}{l}\text { Worse-off } \\
\text { households }\end{array}$} & $\begin{array}{l}\text { Selling wage labour }+ \text { Work as tenants }+ \\
\text { Crop cultivation }\end{array}$ & 22.2 \\
\hline & Selling wage labour + Crop cultivation & 50.0 \\
\hline & Monthly income + Crop cultivation & 27.8 \\
\hline
\end{tabular}

Source: See the text for the discussion

In contrast, $72.2 \%$ of worse-off households was involved in selling wage labour for agricultural or non agricultural activities and/or worked as tenants in the fields of better-off households in addition to crop cultivation (Table 1). On the other hand, these tenancy agreements were not permanent and the power of making the decision regarding continuation or termination of the agreement was vested upon the land owner who was usually a better-off household. Thus the level of importance placed by worse-off households on 
the income obtained through crop cultivation was relatively high. In contrast better off households had a less dependency on farming activities due to off farm income generation activities carried out by them. According to the Table 2 and 3, it is clear that the income generation combinations of better-off households comprised of higher proportion of off farm income generation activities where as that of worse-off households consisted of only farming activities.

Table 2: $\quad$ Type of income generation activities carried out by selected better-off households

\begin{tabular}{cl}
\hline $\begin{array}{c}\text { Sub } \\
\text { case }\end{array}$ & \multicolumn{1}{c}{ Type of income generation activities } \\
\hline 2 & $\begin{array}{l}\text { Boutique, mill, sewing clothes, communication center, animal } \\
\text { husbandry, crop cultivation, paddy buying and selling business, } \\
\text { ROSCRAS }\end{array}$ \\
22 & $\begin{array}{l}\text { Crop cultivation, vehicle brokering, confectionary industry, } \\
\text { ROSCRAS }\end{array}$ \\
17 & $\begin{array}{l}\text { Crop cultivation, carpentry work, hiring out tractor and dynamo, } \\
\text { hiring out van }\end{array}$ \\
39 & $\begin{array}{l}\text { Crop cultivation, quarry, foreign remittances, ROSCRAS } \\
59\end{array}$ \\
& $\begin{array}{l}\text { Assistance Agricultural Research Officer, crop cultivation, } \\
\text { supplying ground nut certified seeds, ROSCRAS }\end{array}$ \\
\hline
\end{tabular}

Source: See the text for the discussion

2 ROSCRAS (Rotating Savings and Credit Association) is a method used by households to save money. Every month a particular amount of money is pooled by every one in the group. The total amount of money pooled per month is given to one person in which the order of receiving money is decided through a lottery. 
Table 3: $\quad$ Type of income generation activities carried out by selected worse-off households

\begin{tabular}{cl}
\hline Sub case & \multicolumn{1}{c}{ Type of income generation activities } \\
\hline 41 & Paddy cultivation, Sell wage labor, work as a tenant \\
57 & $\begin{array}{l}\text { Paddy cultivation, Sell wage labor, work as a tenant } \\
49\end{array}$ \\
34 & Paddy cultivation, sell wage labor \\
& Crop cultivation, sell wage labor
\end{tabular}

Source: See the text for the discussion

Another important observation is the prevalence of permanent monthly income earners in both the better-off and worse-off groups. In spite of having similar income generation activity combinations one group is socioeconomically better-off whereas the other is not. On the other hand, worse-off monthly income receivers had not involved themselves in any other income generation activities other than crop cultivation. In contrast, $36.36 \%$ of betteroff monthly income receivers were carrying out their own businesses in addition to crop cultivation.

\section{Entrepreneurial Qualities and Well-being Status of Rural Pluriactive Households}

Better-off households were exhibiting entrepreneurial qualities in pursuing opportunities and capitalizing them through social networks, pluriactivity and creativity, whereas this was not evident among worse-off households. This behaviour pattern of better-off households had given them the opportunity of extracting benefits from resources, which were not under their control, thus moving beyond boundaries. This will be further elaborated in following sections of the discussion.

\section{Exhibiting Entrepreneurial Qualities through Social Networks}

The interaction among better-off households and between better-off households and rest of the villagers was a crucial factor that enabled them to mobilize resources that were not under their control. Though the existence of a social network was a common scenario in both groups, better-off 
households were having broader social networks that extended beyond the village, whereas those of worse-off households were narrow and basically restricted to the village. On the other hand, the utilization of social networks by worse-off households was limited only to overcome factor market constraints during the crop cultivation period and to find a livelihood during rest of the periods whereas better-off households have utilized it for multiple purposes as described below.

Better-off households had utilized social networks effectively in overcoming resource constraints such as labour, knowledge and low access to formal institutions and in avoiding possibility of resource conflicts arising due to involvement of many income generation activities. As illustrated in the Box 1 , in the case $5^{3}$ an unusual tenancy agreement ${ }^{4}$, had enabled landlord and tenant overcome resource constraints and thus move beyond resource limitations. If there were no such unusual agreements these benefits would not be achieved by them. Such unusual tenancy agreements were always visible among better-off households in which worse-off households were tenants. Such relationships of better-off households with worse-off households had resulted in transferring the success of better-off households to worse-off households as well.

\section{Box 1: Case 5}

Case 5 had land and financial facilities to purchase inputs but lacked enough labour due to usage of his own labour in other ventures which had given him higher profits, while his tenant had surplus labour and a tractor. Thus tenancy agreement allowed them to pool resources to overcome resource constraints by obtaining the advantage of utilizing resources which were not owned by them.

${ }^{3}$ Cases are the households (head of the household in particular).

${ }^{4}$ The tenancy agreements, which didn't comply with the paddy lands act, which was implemented in 1958, were considered as unusual. The law was such that the landowner was bestowed with ten bushels or quarter of the yield, which is lesser, for the provision of the land whereas the tenant received the rest for bearing input cost and labour cost. 
Another strategy adopted by better-off households in order to overcome labour constraints during peak labour demanding periods was the formation of groups. On the other hand, these groups had reduced the cost of production since the better-off households belonging to such groups jointly worked in the fields of group members without any payment.

Better-off households had collectively overcome the constraint of low access to formal financial institutions by introducing a ROSCRAS (Rotating Savings and Credit Association) method, that gave the opportunity of obtaining an interest due to some of the features of an auction. The lump sum of the ROSCRAS money was given to the highest bidder from whom the interest was deducted. Then the deducted amount, which was equivalent to the bid, was divided among the rest. This amount was like an interest received for waiting for another month. In addition this reduces the transaction cost of obtaining formal credit thus providing them an easy and profitable access to finance. This was possible only due to the social network they had built up.

Better-off households had reallocated misallocated resources through social contacts in conquering resource constraints. The interaction between case 39 (Box 2) and his brother shows how these two parties had mobilized resources which were not owned by them. The brother mobilized the knowledge, skills and social contacts of the case 39 while the case 39 utilized the quarry possessed by the brother in order to overcome the constraint of lack of initial capital. From a social point of view this interaction resulted in reallocating the misallocated quarry thus providing employment opportunities to worse-off households as workers of the query. 


\section{Box 2: Case 39}

Case 39 had the advanced technical knowledge of running a quarry and a wider social network but he lacked enough initial capital to purchase a quarry, whereas his brother possessed a quarry, which was running at a loss due to the production of low quality products. They had blended the resources they owned and this enabled them to maneuver a profitable venture where both of them benefited. In addition ten worse-off households were working in the quarry.

Better-off households that were having their own businesses had to rely on customers outside the village since adequate amount of contracts were not received from the village. Communication was the major constraint in contacting outsiders. Thus social networks had been exploited by them in enhancing input and output market opportunities. For example a symbiotic relationship was always observed among masonry work contractors and carpenters in sharing information about contracts where the party who received the contract always tried to introduce the other party. This allowed them to obtain benefits mutually from the social networks of the other party and to overcome the barrier of receiving a lower number of contracts due to inadequate communication facilities.

Better-off households made use of social networks as a strategy of obtaining a secured supply of inputs and demand for outputs by minimizing the risk of uncertainty. The relationship between the persons in case 2 and case 12 (Box 3) enabled case 2 to receive an incessant and secured input for his rice mill and in return case 12 received a continuous demand for the output of his parboiled rice production enterprise. This interaction had given them the advantage of obtaining higher profits through value addition.

\section{Box 3: Interaction between case 2 and 12}

Case 2 received paddy due to 'credit paddy relationship' (will be discussed in detail later) and he sold paddy to case 12 for parboiling and parboiled rice was sold back to case 2 for milling. 
Social networks had been utilized by better-off households in minimizing risk of default where credit paddy exchange relationship is a better example ${ }^{5}$. Boutique keeper involved in lending money and selling goods on credit to worse-off households and the credit was exchanged for paddy during the time of harvesting. The boutique was the place where people purchase their day-to-day needs and gather every day to spend their leisure time and this made it possible for the boutique keeper to build up contacts. It also made it difficult for the borrower to escape without repaying. As discussed, though the resource-starved environment had influenced everybody to be pluriactive, the way in which households benefited out of it was different.

\section{Exhibiting Entrepreneurial Qualities through Pluriactivity}

Better-off households were different in the type of income generation activities carried out and in the way of mobilizing pluriactivity in obtaining benefits out of it. Worse-off households have become pluriactive in order to find a livelihood during the off-season since crop cultivation was not practiced during that time. They sold wage labour to better-off households for carrying out other income generation activities $(72.2 \%$ of worse-off households) during this season whereas better-off households had a combination of income generation activities, which had ultimately minimized income fluctuations and the dependency on agriculture as a source of income. This phenomenon was quantified by giving a score to each income generation activity according to the dependency on rainfall and a final score was obtained with respect to each household (Figure 3). The scores obtained by each household were plotted in a scatter diagram. The diagram indicates that the higher the score the higher the dependency on rainfall. According to the results worse-off households have obtained higher scores compared to betteroff households, which proved the fact that though they were pluriactive their income generation activities were highly dependent upon rainfall, where uncertainty and lack of rainfall had restricted them being better off. In contrast better-off households had moved away from activities, which were dependent upon rainfall, especially to non-agricultural activities. This argument was further facilitated by the type of income generation activities carried out by better-off and worse-off households (Table 2 and 3). According to the view of

\footnotetext{
${ }^{5}$ It is also known that boutique keepers often use such relationships to exploit farmers, but this aspect of the problem was not addressed in the study.
}

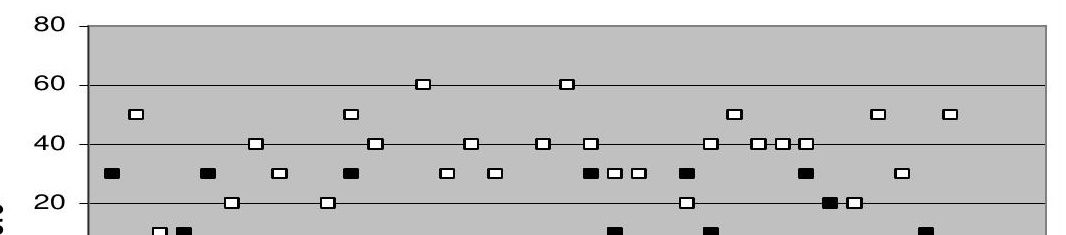


better-off households minimization of income fluctuation had allowed them to plan their spending beforehand and keep targets in their lives.

Figure 3: $\quad$ Dependency on rainfall for income generation activities

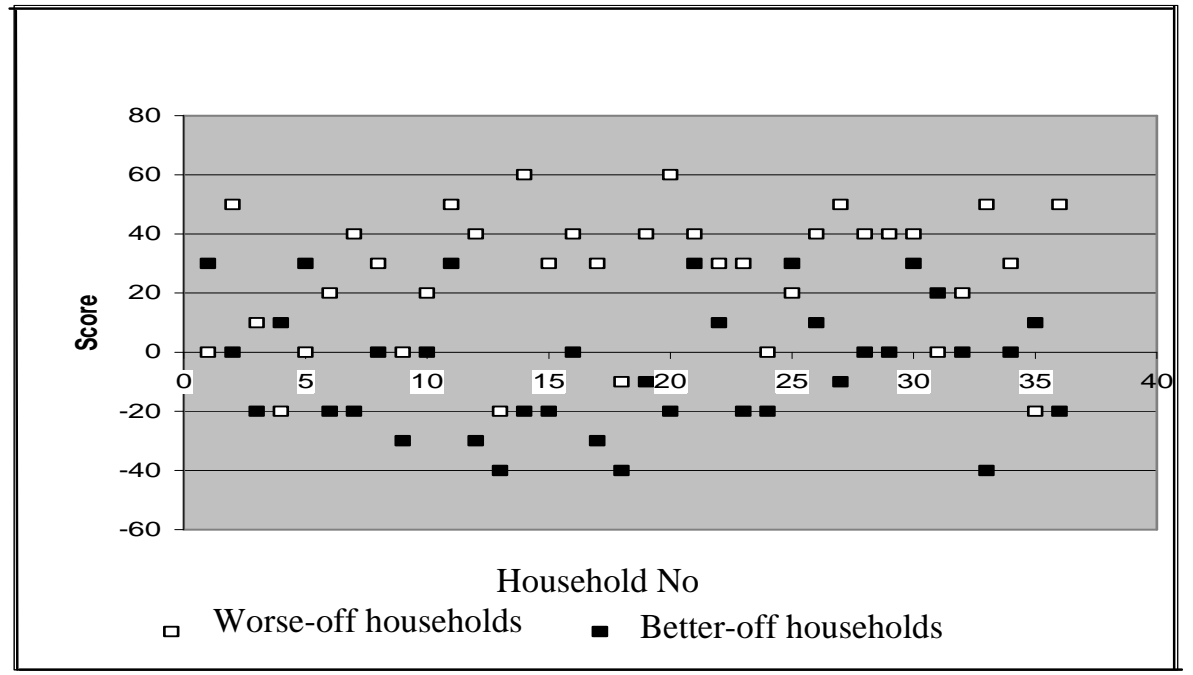

Pulriactivity enabled better-off households to avoid the requirement of borrowing money for paddy cultivation whereas this was not evident among worse-off households. Better-off households were able to utilize profits received from other income generating activities for paddy cultivation. Better-off households practiced reinvesting profits whereas worse-off households have utilized profits basically for consumption. This was clearly indicated by their life goals (Figure 4). Reinvestment was made possible for better-off households due to their involvement in many non-rainfall dependent income generation activities (Tables 2 and 3). Visibility of growth in businesses of better-off households, which was revealed from their life history, was the best proof for this argument. 
Figure 4: $\quad$ Main life goals of better-off and worse-off households

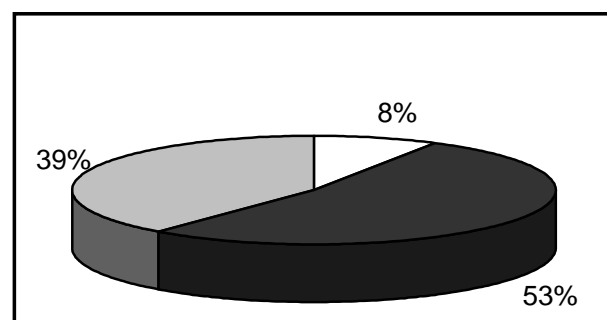

$\square$ BUILDING A HOUSE

-EDUCATING CHILDREN $\square$ DEVELOPING THE BUSINESS

Life goals of better-off households

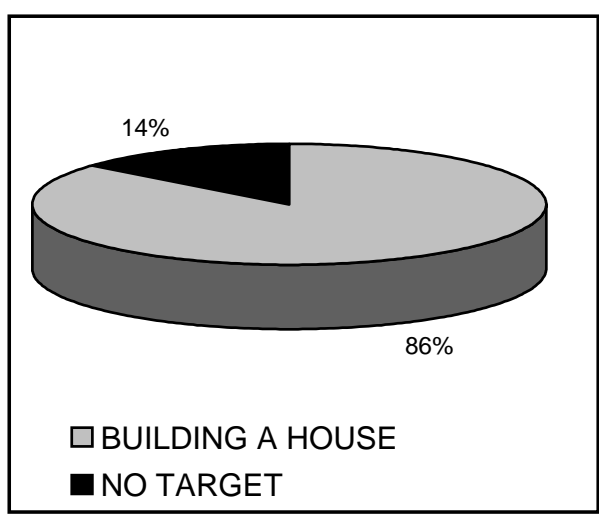

Life goals of worse-off households

Pulriactivity had given better-off households access to information, experience and knowledge, which had become the basis for moving into other income generation activities and to achieve business growth. In case 22 (Box 4), the knowledge on confectionary industries had been obtained while the individual was working as a vehicle broker and this enabled him to learn methods of preparing confectionaries, understand the prevailing demand for confectionaries and to select market segments, which could be best exploited with limited resources.

\section{Box 4: Case 22}

The case 22 had come up with unique recipes of preparing confectionaries by integrating traditional methods with the commercial methods and this had allowed him to compete well with existing sellers and capture a higher market share.

Case 2 is also another example of (Box 5) using pluriactivity as a method of acquiring knowledge and skills. The knowledge on new income generating activities had been obtained by case 2 through diverse income generating activities carried out by him. 


\section{Box 5: Case 2}

In case 2, the knowledge of running a rice mill had been obtained by the boutique keeper, from traders who frequently came to transact with him. The gained knowledge enabled him to expand his business into four hullers, namely rice huller, rubber huller, chillie huller and flour huller.

Pluriactivity had enabled better-off households the opportunity of vertical integration. Case 2 is a good example of households (Box 4) that had a combination of income generation activities, which resulted in vertical integration. He owned a boutique, a money lending business, a rice buying and selling business and rice and flour milling business, in addition to crop cultivation and this had given him the opportunity of using output of one activity as an input to the other. In addition this combination of activities had given him the opportunity of sharing the cost of transportation and storage. He sold goods on credit in the boutique and carried out a money lending business where the debt was exchanged with paddy during the harvesting period. This enabled him to purchase paddy in bulk from villagers at the lowest price without any cash involvement (since paddy was exchanged for credit) and reduce the cost and time of collection of paddy since the villagers were obliged to come to the boutique and sell paddy to the boutique owner in order to repay the debt. This in turn gave him the opportunity of selling rice in bulk during the period rice fetches a higher price. This had increased the bargaining power and ultimately resulted in increasing profits.

Case 17 and 27 are also examples of better-off households (Box 6) that had minimized cost of production through pluriactivity. As illustrated, though the tractor was used for supplementary activities, they were not faced with a resource conflict situation due to usage of it at different time periods. They had minimized the cost and obtained profits instead, by using the same resource for many activities. This unique combination of income generation activities had paved the path for them to be better-off according to their perception. 
Box 6: Case 17 and 27

Case 17 and case 27 carry out carpentry work, hire out generators and tractors in addition to crop cultivation. The tractor was used to transport furniture and machines needed for carpentry work, generate power from generators, plough their own land and it was hired out for paddy cultivation and for generation of electricity.

The benefits obtained through pluriactivity by better-off households were transferred to worse-off households through a multiplier effect. The boutique was the best example for this and the success of the boutique owner has trickled down to the rest of the villagers by way of having access to better goods and services, informal credit facilities, and employment opportunities for worse-off households in the other enterprises carried out by him. The better-off households who were operating their own businesses had provided employment opportunities to $72.2 \%$ of the worse-off households. This was the only source of income during the Yala season since crop cultivation was practiced only during the Maha season. This illustrates how better-off households have contributed to the economic wealth and integrated rural development through exchange of values with worse-off households.

As discussed, though the significance of pluriactivity was different from one better-off household to the other, the commonness was that every one had obtained more than one advantage by being pluriactive in comparison with worse-off households who had become pluriactive just to find a livelihood with the objective of fulfilling their daily consumption.

\section{Exhibiting Entrepreneurial Qualities through Creativity}

Better-off households were creative in spotting opportunities and capitalizing these. Thus this had enabled them to increase market opportunities and acquire higher profits. The unique combination of income generating activities carried out by them was the direct and visible outcome of their creativity (Table 2). As illustrated in case 17 (Box 7), creativity had allowed them how to increase market opportunities and resulted in obtaining higher profits. 


\section{Box 7 : Case 17}

Case 17 had shown his creativity by introducing a dynamo and a tractor to generate electricity to match with the opportunity of finding a tractor free of charge by villagers for a special occasion. Thus he hired out only the dynamo and charged half the rate for hiring a generator. In addition this new method has the capacity of generating more electricity than a generator. Therefore he had been able to capture a better share of the market.

In addition, the ROSCRAS method, the credit paddy exchange relationship showed their creativity.

\section{Conclusions and Policy Implications}

The research study discussed that better-off pluriactive households were different from worse-off pluriactive households in terms of combinations of income generation activities and the way as to how they have obtained benefits through social network, pluriactivity and creativity, that ultimately result in exhibiting entrepreneurial qualities that worse-off households were lacking. Findings were consistent with previous research findings.

In a resource constrained environment income generation activities, other than crop cultivation, make a bigger contribution to household income. Therefore it is important to change the focus from improving 'farm income' to improving 'household income' as highlighted by many researchers. The highest level of economic success and wealth accumulation was visible among households that were operating their own businesses and they have contributed to integrated rural development and economic wealth. Therefore it is important to support this group by way of improving infrastructure, providing market opportunities, credit facilities etc. The households that had become better-off were having the quality of differed gratification. That raises the question of effectiveness of income transfer policies. The better-off households that had their own business had obtained required skills through outside contacts (e.g. skills required for masonry work, carpentry work etc.) whereas worse-off households did not have these skills. Therefore it is worthwhile to provide such training that creates diverse income generation 
activities. As discussed above, not having better marketing facilities for crops resulted in 'crops to credit exchange' thus avoiding ability of reinvesting profits. Therefore improvement of marketing facilities or provision of avenues for value addition could be considered as supportive for the socioeconomic success of pluriactive households. Finally it can be concluded that even though pluriactivity seems to be an imperative solution to poverty, utilization of this tool for policy making should be done with great care since all households have not benefited by being pluriactive. Therefore when policies are drawn, it is important to be sensitive to such differences observed among better-off and worse-off pluriactive households.

\section{References}

Beckford, J.L.W. (1993). A Process for Entrepreneurial Decision? (To Be or Not to Be an Entrepreneur May or May not be the Question, but What is the Answer?). Entrepreneurship, Innovation and Change, 2(2).

Black, P. (1986). A Little Help from Her Friends. Venture, July:52-58.

Bonoma, T.V. (1985). Case Research in Marketing: Opportunities, Problems, and a Process. Journal of Marketing Research, XXII.

Bowler, I., G. Clark, A. Crockett, B. Ilbery, and A. Shaw (1996). The Development of Alternative Farm Enterprises: A Study of Family Labour Farms in the Northern Pennines of England. Journal of Rural studies, 12(3):285-295.

Bryant, C.R. (1989). Entrepreneurs in the Rural Environment. Journal of Rural Studies, 5(4).

Clout, H. (1993). Countryside Change in the United Kingdom. Rapporter Notiser Lunds Universitet Institutionen for Kulturgeograft och Economisk Geografi, 121:62.

Dagher, M.A. and R.D. Christy (1991). Limited Resource Farmers and the Marketing Systems, American Journal of Agricultural Economics, December:1485-1487.

Department of Agriculture. (2000). At the Turn of the Century. Peradeniya. Sri Lanka: Department of Agriculture, Sri Lanka. 
Deparment of Census and Statistics (2000). Household Income and Expenditure Survey 1995/96. Deparment of Sences and Statistics, Sri Lanka.

De Vries, W.M. (1993). Farming with Other Gainful Activities in the Netherlands. Sociologia Ruralis, XXXIII:190-201.

Eisenhardt, K.M. (1989). Building Theories from Case Study Research. Academy of Management Review, 14(4).

Ellis, F. (2000). The Determinants of Rural Livelihood Diversification in Developing Countries, Journal of Agricultural Economics, 51(2).

Evans, N.J. and B.W. Ilbery (1993). Pluriactivity, Part-time Farming and Diversification Debate. Environment and Planning, 25.

Fuller, A.M. (1990). From Par-time Farming to Pluriactivity: A Decade of Change in Europe. Journal of Rural Studies, 6(4):361-375.

Gunathilake, G., M. Perera, R.A.M.C. Wanigarathne, R.E. Fernando, W.D. Laksman, J.K.M.D. Chandrasiri and R.D. Wanigarathne (1992). Rural Povery in Sri Lanka: Priority Issues and Policy Measures. Asian Development Review, 10.

Hartley, J.F. (1989) Leadership and Decision Making in a Strike Organization. In Organizing for Change: Social Movement Organizations in Europe and the United States Greenwich. B. Klandermans (ed.). CT: JAI Press.

Hetland. P. (1986). Pluriactivity as a Strategy for Employment in Rural Norway. Sociologia Ruralis, XXIV( 3/4):385-392.

Hettige, S. (1982). Agrarian Change and the Role of the Entrepreneurial Farmers. Sri Lanka Journal of Agrarian Studies, 3(2).

Johnson, C.J. (1982). Of Strangers and Outsiders: Ethnography and Serendipity in Coastal Communities. Paper Presented in the Annual Meetings of American Anthropological Association, Washington DC. 
Kirk, J. and M. Miller (1986). Reliability and Validity in Qualitative Research, Qualitative Research Methods Series, (1).

Kodithuwakku, K.A.S.S. (1997). Entrepreneurial Process in an Apparently Uniform Context: A Study of Rural Farmers in Sri Lanka. Ph.D. Thesis, University of Stirling, UK.

Kodithuwakku, S.S. and P. Rosa. (2002). The Entrepreneurial Process and Economic Success in a Constrained Environment. Journal of Business Venturing, 17 (5):431-465.

Krasovec, S. (1983). Farmers' Adjustment to Pluriactivity. Sociologia Ruralis, 23(1).

McGrath, R.G. (1996). Options and Entrepreneur: Towards a Strategic Theory of Entrepreneurial Wealth Creation. Academy of Management Proceedings' 96.

Nikajima, C. (1986). Subjective Equilibrium Theory of the Farm Households. Elsevier Publications.

Pandya-Lorch, R. and von J. Braun (1992). Income Sources and Diversification Strategies of the Malnourished Rural Poor. Quarterly Journal of International Agriculture, $31(1): 36-54$.

Reynold, P., D.J. Storey, and P. Westhead (1994). Cross-national Comparision of the Variation in New Firm Formation Rates. Regional Studies, 28(4):443-456.

Rupena-Osolink, M. (1983). The Role of Farm Woman in Rural Pluriactivity: Experience from Yugoslavia. Sociologia Ruralis, 23(1).

Salter, M.S. and W.A. Weinhold (1981). Choosing Compatible Acquisitions. Harvard Business Review, 59:17-127.

Schumpeter, J.A. (1934). The Theory of Economic Development. Cambridge, MA: Harvard University Press. 
Schwab, G., G.A. Barnaby and J.R. Black (1989). Strategies for Risk Management. Farm Management: How to Achieve Your Farm Business Goals, Year Book of Agriculture, USDA.

Scott, M., F. Akin and S. Kodithuwakku (1997). Tackling Adversity with Diversity. In Mastering Enterprise: Your Single-Source Guide to Becoming an Entrepreneur (FT Mastering Series). S. Birley and D.F. Muzyka (eds.). London: Pitman Publishing.

Sri Lanka - Australia Natural Resource Management Project (2004). Base Line Study Report for Walathwewa and Ihalathimbiriyawa Sites. Canabera: URS Sustainable Development.

Stark, O. and D. Levhari (1982). On Migration and Risk in LDCs. Economic Development and Cultural Change. 31:191-196.

Stevenson, H.H., and J.C. Jarillo (1990). A Paradigm of Entrepreneurship: Entrepreneurial Management. Strategic Management Journal, 11.

Tremblay, M. (1982). The Key Informant Technique: A Non-Ethnographic Application. In Field Research: A Source Book and a Field Manual. Burgess, R.G. (ed.). George Allen and Unwin.

Ucbasaran, D., C. Howorth and P. Westhead (2000). Habitual Entrepreneurs: Human Capital, Opportunity Search and Learning. Paper Presented at the Babson-Kauffman Conference, Wellesley, MA: Babson College.

Vyankarnam, S. (1990). When the Harvest is in: Developing Entrepreneurship, Intermediate Technology Publications.

Weersink, A. (1998). Off-farm Labour Decisions by Ontario Swine Producers. Working Paper, University of Guelph: Ontario.

Yin, R.K. (1994). Case Study Research: Design and Methods ( $2^{\text {nd }}$ ed). Sage. 